\title{
Microsoft teams 365 and online learning: The student's perception
}

\author{
Leony Sanga Lamsari Purba* \\ ${ }^{1}$ Department of Chemistry Education, Faculty of Teacher Training and Education, Universitas Kristen \\ Indonesia, Jakarta 13630, Indonesia \\ *Corresponding author: LSLP, leony.purba@uki.ac.id
}

DOI: $10.24114 /$ jpkim.v13i2.26981

Article history:

Received: 12 July 2021

Revised: 20 July 2021

Accepted: 21 July 2021

\begin{abstract}
This study aims to determine the effectiveness of online learning using Microsoft Teams 365. The entire population in this study was used as a research sample, namely all students of the Chemistry Education study program, Indonesian Christian University, Jakarta. Perception data was collected using a questionnaire with dimensions of understanding the material, appearance and accessibility of Microsoft Teams 365. From the results of data processing, it was found that more than $50 \%$ of students' perceptions of Microsoft Teams 365 were good in all indicators of understanding the material and appearance. On the use dimension with connectivity and accessibility indicators more than $50 \%$ of students' perceptions of the Microsoft 365 team are good, but on the quota-saving indicator $42 \%$ of students do not agree.
\end{abstract}

Keywords: Microsoft teams, E-learning, Cemistry

\section{Introduction}

The industrial revolution 5.0 is a challenge as well as an opportunity for universities to improve their graduates. To improve the quality of graduates through the improvement of science and technology, the government has even set national higher education standards, where one of the educational standards is the standard of learning infrastructure (Kemdikbud, 2020). Learning before the COVID-19 pandemic was offline (Purba, 2017) and after that, until now online learning (Novira et al. 2021). The standard of offline learning facilities and infrastructure is different from online (Wulandari et al. 2020; Krismadinata et al. 2020). Online learning requires effective and efficient learning media to improve student achievement (Hodges et al. 2020; Mayer, 2019; Dong et al. 2018).

Various learning media provided by the Indonesian government or which can be accessed for free such as Edmodo (Pardede, 2017), nearpod (Delacruz, 2014; Hakami, 2020), google classroom (Sudarsana et al. 2019), google meet, even evaluation media such as 
kahoot (Purba et al. 2019), quizizz (Purba et al. 2021; Harefa et al. 2020), online crossword puzzles (Sababalat et al. 2021). However, many schools and even universities use learning media that is subject to fees, such as zoom (Limbong et al. 2021), Macromedia flash (Nurfajriani \& Nasution, 2015), Microsoft Teams 365 (Wijayanto et al. 2021).

Microsoft Teams 365 is a virtual learning medium that accommodates collaborative learning (Poston et al. 2020). This learning media has the advantage that it unites conversations, meetings, files, and applications in one system (Widiyarso \& Sutama, 2021), economical internet quota (Rais, 2021), modern features (Fahri, 2020) while the weakness is that educators and students must prepare email addresses with school or college domains (Novita \& Husuhan, 2020).

One of the universities that utilize Microsoft Teams 365 is the Indonesian Christian University (UKI). The chemistry education study program at the UKI Faculty of Teacher Training and Education utilizes Microsoft Teams 365 for online learning during the COVID-19 pandemic. Chemistry learning using Microsoft Teams 365 turns difficult learning into easy (Yuniati, 2020; Wea \& Kuki, 2020; Tataurov \& Shyshkina, 2020).

The features in Microsoft Teams 365 are complete and interesting to use during online learning (Amirullah \& Maesaroh, 2020). Meetings on learning with Microsoft Teams 365 can be recorded and video recordings can be saved and downloaded and shared (Pradja \& Baist, 2019). With the various advantages and disadvantages this media, it is important to analyze the effectiveness of online learning by using Microsoft teams 365 .

\section{Methods}

This research is a descriptive research with a quantitative approach. The population in this study were all students of Chemistry Education Faculty of Teacher Training and Education (FKIP) UKI who were still actively using Microsoft Teams 365, as many as 48 people. The entire population in this study was used as a research sample, this side technique is called a saturated sample (Muhson, 2006). The data collection technique in this study was using a questionnaire on the satisfaction of using Microsoft Teams 365, which was compiled in a google form with detailed indicators as presented in the Table 1.

Table 1

Indicators of Student Perception of the Use of Microsoft Teams 365

\begin{tabular}{c|c|c}
\hline Material Presentation & Display & Use \\
\hline Suitability & Features & Connectivity \\
\hline Structured & Attractiveness & Accessibility \\
\hline Easy to understand & Interactive & Save quota \\
\hline
\end{tabular}

The research instrument after being validated by an expert validator obtained a statement that is feasible to use to collect data in research by following the Likert scale with detailed scores as presented in Table 2. The data analysis technique in this study is descriptive analysis by calculating the percentage score of each statement on the questionnaire. 
Table 2

Likert Scale

\begin{tabular}{c|c}
\hline Score & Category \\
\hline 5 & Strongly Disagree \\
\hline 4 & Disagree \\
\hline 3 & Less Disagree \\
\hline 2 & Agree \\
\hline 1 & Strongly Agree \\
\hline
\end{tabular}

\section{Results and Discussion}

The description of research data regarding student perceptions of the use of Microsoft Teams 365 as an online learning medium, using a questionnaire instrument is presented in Table 3 .

Table 3

Data Description

\begin{tabular}{|c|c|c|c|c|c|}
\hline \multirow[t]{2}{*}{ Statement } & \multicolumn{5}{|c|}{ Respondence Total } \\
\hline & 1 & 2 & 3 & 4 & 5 \\
\hline Microsoft Teams 365 is perfect for delivering material & 0 & 0 & 1 & 31 & 16 \\
\hline $\begin{array}{l}\text { By using Microsoft Teams 365, the delivery of content } \\
\text { is highly structured }\end{array}$ & 0 & 0 & 6 & 34 & 8 \\
\hline $\begin{array}{l}\text { Microsoft Teams } 365 \text { makes it easier to understand the } \\
\text { learning material }\end{array}$ & 0 & 0 & 10 & 33 & 5 \\
\hline The features in Microsoft Teams 365 are very complete & 0 & 0 & 5 & 36 & 7 \\
\hline Microsoft Teams 365 view, very interesting & 0 & 1 & 13 & 29 & 5 \\
\hline $\begin{array}{l}\text { Online learning using Microsoft Teams } 365 \text {, encourages } \\
\text { me to be active in learning. }\end{array}$ & 0 & 0 & 3 & 37 & 8 \\
\hline $\begin{array}{l}\text { Microsoft Teams } 365 \text { supports all types of android and } \\
\text { laptops }\end{array}$ & 0 & 0 & 4 & 30 & 14 \\
\hline $\begin{array}{l}\text { Microsoft Teams } 365 \text { is easy to connect to WIFI or } \\
\text { Mobile Data }\end{array}$ & 0 & 0 & 3 & 34 & 11 \\
\hline Microsoft Teams 365 Save Internet Quota & 1 & 2 & 20 & 18 & 7 \\
\hline
\end{tabular}

Analysis of each dimension and indicator is carried out by calculating the percentage of choices for each assessment indicator. The results of the analysis of students' perceptions of the presentation of material using Microsoft Teams 365 are presented in Fig 1.

The results of the analysis of students' perceptions of the presentation of lecture material using Microsoft Teams 365 during the Covid-19 pandemic condition were in good category because $65 \%$ of students agreed that Microsoft Teams 365 was very suitable to be used to deliver lecture material. $71 \%$ of students agree with the statement using Microsoft Teams 365 , the delivery of the material is very structured and $69 \%$ of students agree with the statement Using Microsoft Teams 365 makes it easier to understand the learning material 
presented. The positive perception of students towards the use of Microsoft Teams 365 when viewed from the indicators of presentation of the material according to its advantages, namely being able to share screens and available whiteboards to deliver lecture material. Students rated their collaborative skills as good to very good and felt that the project was effective in developing these skills (Buchal \& Songsore, 2019). The results of the analysis of student perceptions of dimension the appearance of Microsoft Teams 365 are presented in Fig 2.

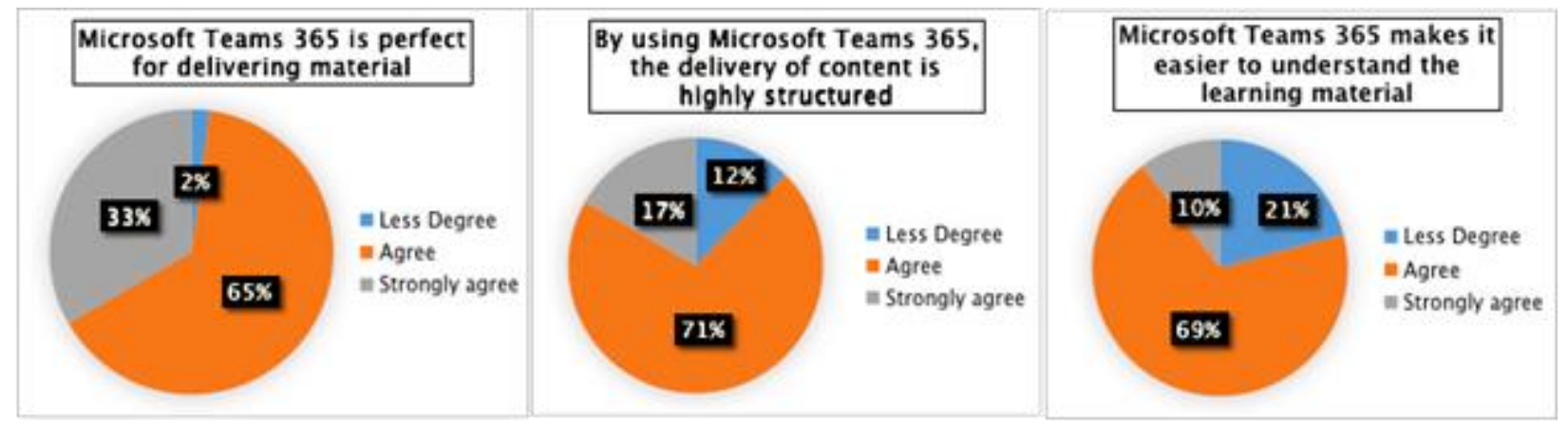

Fig 1. Student perceptions of presenting material using Microsoft Teams 365

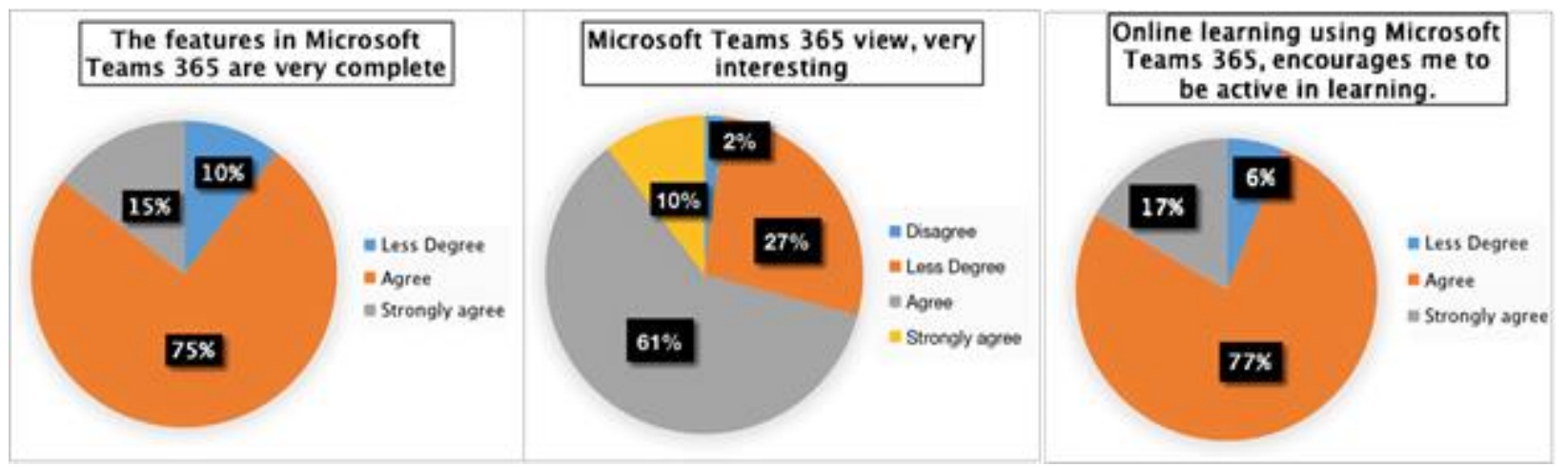

Fig 2. Student perception of the appearance of Microsoft Teams 365

Referring to Figure 2 above, the results obtained, $75 \%$ of students agree that the features in Microsoft Teams 365 are very complete, $61 \%$ agree that the features in Microsoft Teams 365 are very interesting and $77 \%$ agree and even $17 \%$ strongly agree with the statement Online learning using Microsoft Teams 365, encourages me to be active in learning. According to research results, Microsoft Teams 365 has many features that allow learning more effectively and efficiently (Hubbard \& Balley, 2018), have amazing features (Yen \& Nhi, 2021).

The results of data analysis on student perceptions of dimension the use of Microsoft Teams 365 are presented in Fig 3. The statement that Microsoft Teams 365 supports all types of Android and laptops, $63 \%$ answered agree and even $29 \%$ answered strongly agree by students as respondents. $71 \%$ of students agree and $23 \%$ strongly agree that Microsoft Teams 365 is easy to connect to WIFI or Cellular Data. For the Microsoft Teams 365 statement that saves internet quota, $2 \%$ strongly disagree, $4 \%$ disagree, $42 \%$ disagree, $37 \%$ agree and only $15 \%$ of students strongly agree. Microsoft Teams 365 as an internal communication tool is a 
digital tool that you may find easy to use (Vauhkonen, 2020). Student perceptions regarding the use of Microsoft Teams 365 which are less cost-effective because students of the Chemistry Education Study Program FKIP UKI are scholarship students living in UKI dormitories.

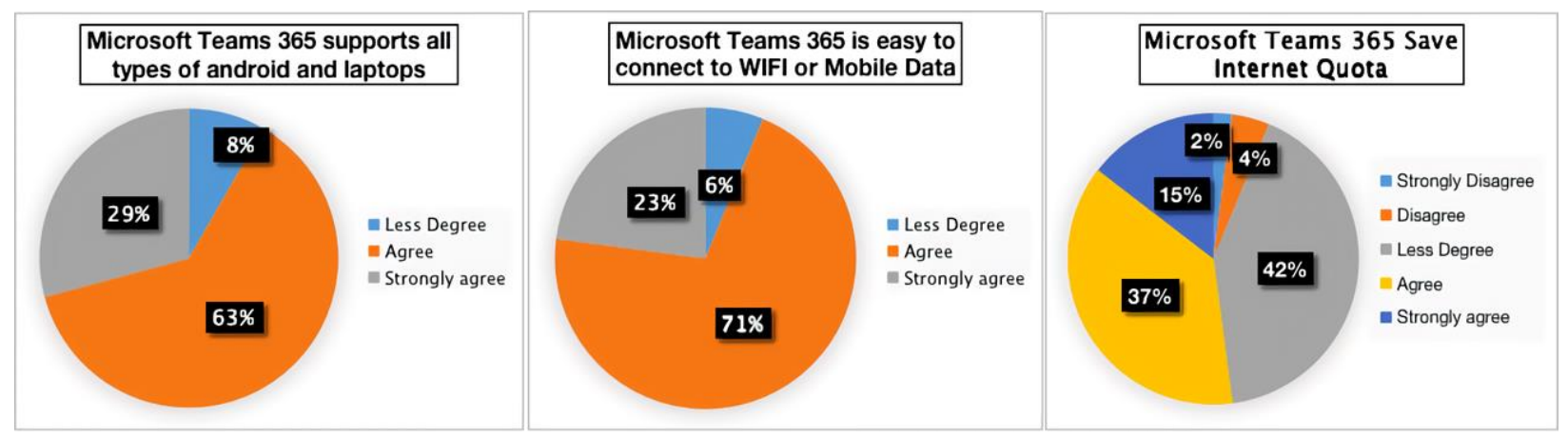

Fig 3. Student perceptions of the accessibility of microsoft teams 365

\section{Conclusion}

Students' perceptions of understanding the material by using Microsoft Teams 365 , the appearance and accessibility of Microsoft Teams 365 are good, it's just that they are less efficient on internet quota.

\section{Acknowledgment}

Researchers would like to thank the Universitas Kristen Indonesia for providing facilities for the implementation of this research.

\section{References}

Amirullah, G., \& Maesaroh, M. (2020). Pelatihan pengembangan kelas digital berbasis microsoft 365 di sekolah Muhammadiyah DKI Jakarta. Community Development Journal: Jurnal Pengabdian Masyarakat, 1(3), 223-227.

Buchal, R., \& Songsore, E. (2019). Using microsoft teams to support collaborative knowledge building in the context of sustainability assessment. Proceedings of the Canadian Engineering Education Association (CEEA). DOI:10.24908/pceea.vio.13882

Delacruz, S. (2014). Using Nearpod in elementary guided reading groups. TechTrends, 58(5), 62-69. DOI:10.1007/s11528-014-0787-9

Dong, X., Chang, Y., Liang, S., \& Fan, X. (2018). How online media synergy influences consumers' purchase intention. Internet Research, 28(4), 946-964. DOI:10.1108/intr-08-2017-0298

Fahri, M. U. (2020). Meeting online dengan microsoft teams. DOI:10.31219/osf.io/6cufq

Hakami, M. (2020). Using nearpod as a tool to promote active learning in higher education in a byod learning environment. Journal of Education and Learning, 9(1), 119-126. DOI:10.5539/jel.v9n1p119

Harefa, N., Sinaga, M., \& Silaban, S. (2020). Students perception and interest on chemistry: Learning evaluation integrated quizziz media. Jurnal Pendidikan Kimia, 12(3), 143-150. DOI:10.24114/jpkim.v12i3.21163

Hodges, C., Moore, S., Lockee, B., Trust, T., \& Bond, A. (2020). The difference between emergency remote teaching and online learning. Educause Review, 27(1), 1-9. 
Hubbard, M., \& Bailey, M. J. (2018). Mastering microsoft teams. Mastering Microsoft Teams. DOI:10.1007/978-1-4842-3670-3

Kemdikbud, (2020). Peraturan Menteri Pendidikan dan Kebudayaan Republik Indonesia Nomor 3 tentang Standar Nasional Pendidikan Tinggi. Jakarta: Kemdikbud

Krismadinata, K., Verawardina, U., Jalinus, N., Rizal, F., Sukardi, S., Sudira, P., ... Novaliendry, D. (2020). Blended learning as instructional model in vocational education: literature review. Universal Journal of Educational Research, 8(11B), 5801-5815. DOI:10.13189/ujer.2020.082214

Agustinus Palimbong, M. L., Asnah Limbong,. (2021). Survey online learning in the pandemic time of covid-19, Case study at Universitas Kristen Indonesia. Psychology and Education Journal, 58(2), 6041-6049. DOI:10.17762/pae.v58i2.3080

Mayer, R. E. (2019). Thirty years of research on online learning. Applied Cognitive Psychology, 33(2), 152-159. DOI:10.1002/acp.3482

Muhson, A. (2006). Teknik analisis kuantitatif. Universitas Negeri Yogyakarta. Yogyakarta.

Nurfajriani, N., \& Nasution, Z. (2015). Pengaruh software macromedia flash pada pembelajaran dengan model kooperatif tipe team assisted individualization terhadap hasil belajar kimia siswa pada pokok materi termokimia. Jurnal Pendidikan Kimia, 7(3), 18-24. DOI:10.24114/jpkim.v7i3.4268

Novita, D., \& Hutasuhut, A. R. (2020). Plus minus penggunaan aplikasi aplikasi pembelajaran daring selama pandemi covid 19. Unimed Medan, June, 1-11.

Novira, P., Silalahi, A., \& Silaban, S. (2021). Analysis effectiveness of the online learning through the use of google classroom during the covid-19 pandemic. Jurnal Pendidikan dan Pembelajaran Kimia, 10(1), 88-93. DOI: 10.23960/jppk.v10.i1

Pardede, P. (2017). Current studies on the use of edmodo in efl learning: A review. JET (Journal of English Teaching), 3(3), 244-258. DOI:10.33541/jet.v3i3.1332

Pradja, B. P., \& Baist, A. (2019). Analisis kualitatif penggunaan microsoft teams dalam pembelajaran kolaboratif daring. SENATIK, 415-420.

Poston, J., Apostel, S., \& Richardson, K. (2019). Using microsoft teams to enhance engagement and learning with any class: It's fun and easy. Pedagogicon Proceedings, p 1-5.

Purba, L. S. L. (2017). Pengaruh penerapan model pembelajaran kooperatif tipe two stay-two stray (ts-ts) terhadap hasil belajar dan aktivitas belajar siswa pada pokok bahasan koloid. EduMatSains: Jurnal Pendidikan, Matematika dan Sains, 1(2), 137-152. DOI:10.33541/edumatsains.v1i2.239

Purba, L. S. L., Harefa, N., Afridika, S., \& Savera, D. (2021). The differences of a chievement of the national olympiad in chemistry at the public and private senior high school by utilizing quizizz media. Jurnal Pendidikan Kimia, 13(1), 69-77. DOI:10.24114/jpkim.v13i1.24146

Purba, L. S. L., Sormin, E., \& Harefa, N. (2019). Effectiveness of use of online games kahoot! chemical to improve student learning motivation. Jurnal Pendidikan Kimia, 11(2), 57-66. DOI:10.24114/jpkim.v11i2.14463

Rais, M. (2021). Persepsi mahasiswa terhadap pembelajaran jarak jauh menggunakan microsoft teams. DOI:10.31219/osf.io/7dwvm

Sababalat, D. F., Purba, L. S. L., \& Sormin, S. (2021). Efektivitas pemanfaatan media pembelajaran teka-teki silang online terhadap peningkatan minat belajar siswa. EduMatSains: Jurnal Pendidikan, Matematika dan Sains, 6(1), 207-218. DOI:10.33541/edumatsains.v6i1.2959

Sudarsana, I. K., Putra, I. B. M. A., Astawa, I. N. T., \& Yogantara, I. W. L. (2019). The use of google classroom in the learning process. Journal of Physics: Conference Serie, 1175 012165. DOI:1088/17426596/1175/1/012165

Tataurov, V., \& Shyshkina, M. (2020). The method of using microsoft office 365 services to support students collaborative learning. Physical and Mathematical Education, (2(24)). DOI:10.31110/24131571-2020-024-2-020

Vauhkonen, O. (2020). Implementation of Microsoft Teams at organizations in Finland. 
Wea, K. N., \& Kuki, A. D. (2021). Students' perceptions of using microsoft teams application in online learning during the covid-19 pandemic. Journal of Physics: Conference Series, 1842 012016. DOI: $10.1088 / 1742-6596 / 1842 / 1 / 012016$

Widiyarso, T. H., \& Sutama, S. (2021). Efektifitas penggunaan microsoft teams dalam pembelajaran elearning bagi guru selama pandemi covid-19. Didaktis: Jurnal Pendidikan dan Ilmu Pengetahuan, 21(1).

Wijayanto, Y. R., Andayani, A., \& Sumarwati, S. (2021). Utilization of microsoft teams 365 as an alternative for distance learning media amid the Covid-19 pandemic. International Journal of Multicultural and Multireligious Understanding, 8(2), 87-93. DOI:10.18415/ijmmu.v8i2.2333

Wulandari, T., Agrita, T. W., \& Hidayatullah, K. (2020). Analisis perbandingan perkuliahan online dan offline terhadap mahasiswa STKIP Muhammadiyah Muara Bungo. Proceeding National Conference: Education, Social, Science, and Humaniora, 2, 64-68.

Yen, T. V. M., \& Nhi, N. T. U. (2021). The practice of online english teaching and learning with microsoft teams: from students' view. AsiaCALL Online Journal, 12(2), 51-57.

Yuniati, Y. (2020). Strategi pembelajaran daring ilmu kimia: dari yang sulit menjadi mudah. Katalog Buku Karya Dosen ITATS, 67-90. 